\title{
Calle14: entre la institucionalidad y la desobediencia epistémica
}

\section{Pedro Pablo Gómez}

Editor

ppgomez@udistrital.edu.co

Como citar este artículo: Gómez, P. P. (2022). Calle14:

Entre la institucionalidad y la desobediencia epistémica. Calle14: revista de investigación en el campo del arte. 17(31), pp. 10-15.

https://doi.org/10.14483/21450706.18753 
En el año 2006 cuando nos proponíamos elaborar el proyecto de la Revista Calle14 para su institucionalización surgió, entre otras, la pregunta acerca de lo que significa agenciar una revista científica desde el campo de las artes, acogiéndonos a lógicas que aun no comprendíamos muy bien. El subtítulo mismo de 'revista de investigación en el campo del arte', da cuenta del debate que en aquellos años sosteníamos en la naciente facultad, cuando pasábamos a ser parte integral de la Universidad Distrital, una institución en la que las ciencias 'duras' tienen preponderancia sobre las ciencias humanas, las ciencias sociales y las artes. A la sazón, los conceptos de campo del arte y el de prácticas artísticas eran fundamentales para la construcción de las políticas culturales del Distrito Capital 2004-2016. Y claro está, la Academia Superior de Artes (ASAB) fue un lugar donde se debatió y aportó para la elaboración de esas políticas.

Queríamos tener una revista que diera cuenta de los debates contemporáneos de las artes, publicada con regularidad y con alta calidad editorial, que no obedeciera estrictamente a las iniciativas de las directivas institucionales, como ocurría con la revista ASAB. Una publicación de alta calidad editorial, pero de carácter endógeno y sin una periodicidad constante.

Obedecimos a los criterios de Colciencias y con el segundo número, dedicado al tema del museo y lo museal, en 2008 logramos la clasificación en Publindex en Categoría C, la más baja del ranking la cual, no obstante, celebramos como un gran logro, pues Calle14 era una de las 3 revistas de artes que formaban parte del índex nacional. Como acto desobediente, incluimos en la tipología de artículos la denominación: artículo de investigación artística, científica o tecnológica. Asímismo, decidimos incluir resúmenes en lengua quechua, aun sabiendo que en las bases de datos y en los sistemas de indexación y referencia no existen casillas para lenguas ancestrales americanas. Además, con la asesoría de la experta en derechos de autor Carolina Botero, incluimos en la política editorial el licenciamiento de Creative Commos que hizo posible el acceso abierto a los contenidos de la revista y el ingreso a la plataforma OJS. Un proceso que luego acogió la universidad Distrital para todas sus revistas científicas. En todo esto nos guiamos por la idea de que es posible incidir desde dentro en las instituciones jerarquizadas por la colonialidad del saber.

Ya para 2016 habíamos logrado varias indexaciones internacionales, gracias a la confianza de los investigadores y creadores en nuestra revista que como medio de comunicación facilita el acceso a resultados de investigación de manera libre. Pero ese mismo año, debido a circunstancias institucionales y al cambio en los términos 
de clasificación de Publindex, no alcanzamos la clasificación en el índex nacional. Nos dimos cuenta de que para lograr la clasificación debíamos entrar en la competencia de los cuartiles y del denominado Índice H con las revistas del área de humanidades, en la que está subsumida el área de las artes. Y claro está, en las humanidades hay revistas que tienen muchas mayor cientificidad y citaciones que las revistas de arte.

En consecuencia, explicamos rápidamente esta situación a los miembros de los comités y autores de la revista, quienes nos han sorprendido gratamente manteniendo el flujo de envíos de artículos para evaluación y publicación. Es más, el envío de artículos de autores internacionales ha incrementado su proporción con respecto a los autores nacionales y de la institución editora. Como resultado, Calle14 es una revista cada vez menos endógena y más internacional, siendo las comunidades académicas y creadoras las que le han dado este carácter.

En estos avatares, comprendimos que los criterios de Publindex son una adaptación obediente a las lógicas de las revistas científicas del primer mundo, muchas de ellas con ánimo de lucro, lógicas que funcionan a su manera en el Primer mundo, pero en el tercero hacen visible la colonialidad del conocimiento, la dependencia y el subdesarrollo. En las revistas de primer orden circulan los frutos de la 'ciencia neoliberal' que protege los resultados de investigación con patentes y controla el acceso mediante el pago, tanto para publicar como para leer, amparados en los derechos de propiedad privada y el copyright. La lógica de Publindex de nuestro país, que forma parte del direccionamiento empresarial y neoliberal de la ciencia, ha sido ampliamente cuestionada por académicos de las ciencias sociales, las ciencias humanas y las artes y claro por editores de revistas de estas mismas áreas. Se propone, en cambio, un horizonte de democratización de las áreas del conocimiento, de sus agentes, sus productos de investigación y creación, así como de los medios de circulación y socialización. En este contexto, estamos del lado de los diferentes niveles de copyleft del libre acceso, la ética de la investigación y la creación además de la función social del conocimiento; y más cuando se trata de una publicación editada en una institución de carácter público como la Universidad Distrital Francisco José de Caldas.

Así, en estos últimos años hemos tenido que adaptarnos a la disminución del apoyo institucional para la edición completa e impresa de la revista; a enfrentar recetas de sobrevivencia y propuestas de fusión que provienen de expertos que nos consideran en minoría de edad académica. No obstante, estamos convencidos que la Facultad de Artes ASAB tiene la capacidad suficiente para encargarse de Calle14, una publicación 
que, por lo demás, ha sido clave para la acreditación de alta calidad de varios de sus programas de formación de pregrado y para la apertura de sus dos programas de posgrado.

Por supuesto que no hemos cesado, ni cesaremos, en el esfuerzo de mantener la alta calidad editorial de la revista y también de reingresar al listado de revistas clasificadas por Publindex. Con esto último, no buscamos recuperar la clasificación para mostrar una vez más que las artes obedientes pueden ser aceptadas en el foro de la ciencia. Lo hacemos para que nuestra voz disonante y las voces de las imágenes de los artistas y creadores que publicamos en nuestras páginas, puedan unirse a las otras voces que cuestionan, desde el interior del sistema, la colonialidad del conocimiento y su lógica de producción capitalista y neoliberal, su control por parte del Estado y su circulación y apropiación regida por las lógicas transnacionales del mercado. 